\title{
Impact Of The International Grocery Chain On The US Online Grocery Business
}

Louis J. Zivic, (E-mail: lzivic@fsc.edu), Fitchburg State College

Timothy P. Shea, (E-mail: tshea@umassd.edu), University of Massachusetts, Dartmouth

\begin{abstract}
The established, United States based brick-and-mortar grocery chains have been slow to enter the online grocery business. This paper, the third in a series, explores whether that is still the case in 2001, how the new pure-play online grocers are doing in the aftermath of the collapse of the technical sector of stocks in early 2001, and the role that internationally-based grocery chains are taking in the US marketplace. Somewhat surprisingly, some internationally-based grocery chains are moving aggressively into both the brick-and-mortar and the online grocery business in the United States.
\end{abstract}

\section{Introduction}

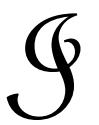

n spite of spirited projections for rapid growth (Sloane, 2001), the online grocery business in the United States reports mixed results over the past few years. The established, brick-and-mortar grocery chains have been slow to enter the online grocery business, waiting to see if online companies could prove industry profit potential. Along with the general crash of many pure play online companies during 2000, online grocers have fared the worst with some, like Streamline.com Inc., and ShopLink.com even declaring bankruptcy (Janoff (b), 2001).

The news media continues to highlight the plight of the dot-com world and paint a picture that misleads rather than informs. Despite this negativity, e-commerce is still very viable. According to the Gartner Group, business-to-business (B2B) e-commerce will grow to $\$ 2.1$ trillion in 2002. Yes, trillions. This forecasted explosion of B2B activity is generated by a mix of technology spending, investment financing, and the efforts of brick-toclicks businesses to implement e-commerce activities.

The business-to-consumer (B2C) forecast is impressive as well, but at a much smaller scale. Based upon the April 2000 report, "The State of Online Retailing 3.0" by the Boston Consulting Group for Shop.org, the trade association for online retailers, consumer revenues will increase from $\$ 33.1$ billion in 1999 to more than $\$ 100$ billion in 2001. Online grocery sales are predicted to reach several billion dollars in the United States by 2003, a small fraction of the retail grocery market but still significant dollar amounts (Sloane, 2001).

In 1999, we completed research in the retail food industry that gave a current status of e-commerce utilization in the New England retail food industry. At that point, the results of the survey research suggested that they were acting as late adopters of e-commerce. Also, the role and future of online startups, such as Peapod, Streamline, and Shoplink, was ongoing and promising. In addition, at that time, foreign super market giants had a fledging, but very strong interest in acquiring selected chains in the United States. (Zivic and Shea, 2000) In 2000, the same survey was replicated. While New England food retailers seemed much more active in developing an epresence and building a B2B capability, the overall tone seemed to be one of wait-and-see for B2C -- online grocery shopping. Delivery costs, lukewarm consumer reaction, and lack of profits was holding back large-scale acceptance (Shea and Zivic, 2001).

Readers with comments or questions are encouraged to contact the authors via email.

This paper, a third in a series, looks at the current state of online grocery shopping in the United States and 
also expands the horizon by looking at international grocery retailers and their efforts to date in successfully incorporating the online grocery business. Are their experiences similar? Have they been more successful? First, the US marketplace is examined.

\section{US Marketplace}

The research methodology for the past two years has been to survey local retail food chains in New England through telephone surveys. Garnering information has proven to be difficult with the generally conservative, late adopter culture of New England food chains. As a result, when seeking information at a national level this year, the methodology was modified from surveying an area (attempting interviews with all the major food chains in an area) to conducting a literature search and telephone interviews with a select few leaders in the retail grocery business in the United States.

The business literature is abundant and ongoing regarding the significant impact of B2B activities such as warehouse management and supply chain applications, while B2C such as electronic retailing has had disappointing growth. For example, online sales during the Christmas season in 2000 using Visa only represented 3.5 percent of spending on its credit cards (Hansell, 2000; Janoff (a), 2001). In conjunction with telephone conversations with a few leaders in the industry, several themes emerged:

(1) B2B is the favored e-commerce activity by all the food chains interviewed with all the chains reporting major gains.

(2) B2C by large chains themselves is limited and not currently in widespread use.

(3) Some chains get a look at new ideas and technology by outsourcing research and development. For example, Jewel food became an investor in online grocer Peapod (Jones, 2001).

(4) Online grocers, entrepreneurs outside conventional food chains, continue to test the B2C pure ecommerce concept with mixed results. They are typically located and operated in large metropolitan areas. For example, HomeRuns.com has identified several key factors for a viable online grocery store: manageable delivery costs, "strong Internet accessibility, a solid workforce, and a high disposable income" (Gebhardt, 2001).

One view of the online grocery business in the United States reveals a muddled picture of how much consumer value exists and whether it can be profitable outside of urban areas or specialty foods such as wine, ethnic food, or online versions of food catalogs. Perhaps, in line with Chritensen's best seller The Innovator's Dilemma (Christensen, 1997), food retailers in the United States view the B2C movement as a disruptive technology or idea where a new, inferior product steals market share from companies that focus on making existing product's or more sophisticated industries (Jones, 2001). Put in simpler terms by a Kroger spokesperson, "It still is not profitable, but we are continuing to tweak and test it" (Sloane, 2001).

Another possibility reveals ventures into the online grocery business are pausing as corporate growth slows in 2001 and the whole nature and future on the New Economy are revisited. In other industries, companies are souring on the management ideas of the New Economy with unusual speed. For example, an annual 2001 survey by Bain \& Company shows that $45 \%$ of companies that had used corporate venturing (the practice of investing in startups) sometime in the past five years quit in the year 2000. Nineteen percent no longer use customer relationship management (CRM). As companies' growth slows during 2001, the more time-tested tools such as strategic planning, mission statements and benchmarking are moving back to the forefront (Jones, 2001). Amazon.com, a leader in online retailing, is now looking to shore up its' core businesses of books, video, and music. As the CEO of American Express states succinctly, "Through our long history we have seldom made any money when we have departed from the core" (Zook, 2001). And, with current valuations of the top grocery retailers positive for 2001, less reason exists to add risk via extensive investment in the uncertain online grocery business (Barnwell and Beliakov, 2001). 
Be it wisdom or luck, the retail food industry with a "wait-and-see" attitude regarding B2C in the grocery business (online groceries) and its focus on its core business (the bricks-and-mortar store) over the past few years seems to have had the right strategy. Their move into developing B2B capabilities has paralleled other industries' efforts where savings along the supply chain are far more predictable than on the online consumer sales side. In addition, by waiting, a whole new generation of off-the-shelf e-procurement applications has evolved significantly reducing time-to-market for B2B applications (Anonymous (b), 2001). The next section discusses the growing role of the international food chain on the United State's retail and online grocery business. One question to address is why was Chicago-based Peapod, one of the first major pure play dot-com grocery companies purchased by Ahold, a European food retailer? Why is Tesco, the largest online grocer in Britain, entering the United States? Meanwhile, US supermarket chains seem to be in no rush to expand their online grocery ordering services beyond limited market testing. Is there something happening in the International retail grocery business different than in the United States? The next section explores the international retail grocery industry for an answer.

\section{The International Grocer In The United States}

Selling internationally often times becomes a mixed bag with the promise of new or rapidly growing markets often offset by a variety of political, cultural, economic, procurement, distribution, transportation, and currency exchange issues. Additionally, companies risk the worldwide reputation of their name or brands with every new, local presence on the global stage (Anonymous (a), 2001). This problem becomes especially acute in food retailing where food safety is an important concern (Hollingworth, 2001). However, the interest in international sales is currently spurred by the slowing growth in the United States and promising growth in other parts of the world. Europe expects to have higher growth, 3\% overall, than the United States. Overall, Latin America -- with the exception of Argentina and its recession -- has strong economic forecasts. Even Russia is markedly more settled compared to just two years ago. Alternatively, the chance for foreign-based retailers in Canada is small due to Canadian regulators. Overall, as put succinctly by investment expert Stephen Jarislowsky, "Globalization is the game" (Janoff (a), 2001).

In terms of online selling, the number of Internet users in many of these areas doubles every year, albeit off a much smaller base than the United States. In Asia the online market may be not through the traditional Internet but through the wireless web (Andruss and Bertagnoli, 2001). Issues such as standardization versus local customization of web sites is currently being worked out with corporate needs for economies of scale and promoting global brands being balanced with local branches trying to match product offerings with their customers' cultural reference points and preferences (Mazur, 2001).

One example of a successful niche food retail company is Fruitcake.com, a specialty company whose main product has been fruitcakes since its founding in 1896. For them, e-commerce simply becomes an extension of their long-standing mail-order business. Fruitcake.com ships about 100,000 packages a day all around the world during its peak season, pre-Christmas. Overall, online orders represent about ten percent of the company's total sales. The key to their success, according to their CEO, is that "We have a 104-year-old back end (to deliver the products)" (Davis, 2000).

Two examples of large, international grocery store chains are IGA, and Ahold. IGA International, based in Chicago, is in the top 10 in world food supermarketing as a "voluntary supermarket network with aggregate sales of more than $\$ 21$ billion per year". IGA member stores number 4000 independent storeowners in over 40 countries around the world with about one-half of the stores outside the United States (IGA International, 2001). Their advantage is local ownership that decides product assortment, pricing, and store formats combined with the economies of scale in terms of international marketing, buying, and distribution. According to IGA Senior VicePresident International, Paulo Goelzer, "My focus is trying to build more than a global company by giving IGA members inside individual countries a competitive advantage through our system" (Anonymous (a), 2001). A small percentage of these stores offer online shopping, B2C. However, back-office, B2B activities such as assessment are now electronic. 
Royal Dutch Ahold, the international food retailer and foodservice giant based in the Netherlands, has about 8,500 markets in the United States, Europe, Latin America, and Asia, about $\$ 50$ billion in annual sales - over one-half in the United States, the only European grocery retailer to become a dominate player in the United States. Their total sales increase of $56 \%$ in 2000 made them the second largest food retailer in the world after France's Carrefour. They continue with aggressive plans for growth in 2001 by continuing a multi-channel, multi-region, and multi-format strategy. Like IGA, they subscribe to the combination of local management while enjoying the economies of scale possible for a large company to create competitive advantage. Also like IGA, there is significant effort being put into using technology to reduce costs through B2B applications. Unlike IGA, Ahold's has ventured aggressively into the B2C online grocery business in the United States through their purchase of Peapod -- an early entrant in the online grocery business in the United States - and their own Internet operations in Holland. The Holland operations have been profitable for two years. Peapod is expected to break even by 2003 (Duff, 2001; Barnwell and Beliakov, 2001).

Tesco PLC is the largest online grocery service in Britain with over $\$ 400$ million in annual sales and profitable. They just recently entered the United States market after buying a 35\% stake in GroceryWorks. Rather than relying on centralized warehouses, as the failed Webvan Group Inc. and the old GroceryWorks did, Tesco's business model focuses on deliveries from individual supermarkets (Slingsby, 2001; Stecklow, 2001).

The overall emphasis in the international market seems to be more aggressive growth as well as larger scale online grocery initiatives than their American counterparts. The next section suggests some reasons why.

\section{Conclusion}

There is currently more active participation in the online grocery business in the United States by European companies than by American companies. This trend suggests further investigation. Partch (2000) suggests two factors hindering American online stores:

- The 80 to 90 percent redundancy in products in every brick-and-mortar supermarket, which is being replicated by most online grocers, is not viable

- The $\$ 30$ billion-plus in trade promotion perpetuates an economic straitjacket in the US retail grocery business

Hansell (2000) suggests that long-standing brand acceptance engendered by the large brick-and-mortar chains causes Internet shoppers to flock to online versions of the brick-and-mortar stores when they appear rather than the new, pure-play online options. In addition to a strong customer base, Gary Rhodes, a senior spokesman for Kroger, states "Supermarkets can offer multiple ordering alternatives and flexible delivery options, including customers picking up their orders at the store" (Sloane, 2001).

Two years ago, American brick-and-mortar retail grocery chains were waiting for the pure-play dot-com online grocers to prove the concept profitable. To date, they have largely failed. In an unexpected twist, the American chains seem content to continue to concentrate on B2B capabilities and tinker with online grocery sales while international retail grocers are moving far more aggressively. Will the international companies prove retail online groceries to be profitable? Stay tuned.

\section{References}

1. Anonymous (a), "Think Globally, Act Appropriately.", Progressive Grocer, $75^{\text {th }}$ Anniversary IGA Supplement. New York; March, 2001, pp. 21-26.

2. $\quad$ Anonymous (b), "In Brief: E-Marketplace Spending Seen Nearly Tripling by '05.” American Banker, New York; Volume 166, Issue 66, April 5, 2001, p. 7+.

3. Andruss, Paula Lyon and Lisa Bertagnoli. "Europe, Latin America Hold Most Marketing Promise." Marketing News. Chicago; Volume 35, Issue 1, January 1, 2001, p. 11+.

4. Barnwell, Thomas and Victor Beliakov. "Food for Thought." Asian Business. Hong Kong; Volume 37, 
Issue 6, June, 2001, pp. 66-67.

5. Christensen, Clayton. The Innovator's Dilemma. Harper Business, 1997.

6. Davis, Jessica, "Fruitcake.com's Simple Strategy Propels Them Into an International Market." InfoWorld. Framingham, Massachusetts; Volume 22, Issue 49, December 4, 2000, p.49+.

7. Duff, Mike, “Ahold Revewls Aggressive Expansion.” DSN Retailing Today. New York; Volume 40, Issue 9, May 1, 2001, p. 3+.

8. Gebhardt, Sara. "Convenience Spurs Online Food Sales; Howard Service Next" The Washington Post. Washington, D.C.; December 21, 2000, p. M05+.

9. Hansell, Saul. "Traditional Chains Making Inroads in the Online Market." New York Times. New York; December 23, 2000, p. C1+.

10. Hollingsworth, Jill. "Going Global." Supermarket Business. New York; Volume 56, Issue 3, March 15, 2001, p. $79+$.

11. IGA International Homepage, www.igainc.com/IGAinternational/interntHome.htm , accessed June 26, 2001.

12. Janoff (a), Barry, “Face Off.” Progressive Grocer. New York; Volume 80, Issue 3, March, 2001, pp. 14-20.

13. Janoff (b), Barry, "Boston E-Party.” Progressive Grocer. New York; Volume 80, Issue 2, February, 2001, pp. 57-58+.

14. Jones, Del. "New Economy Ideas Bite the Dust Faster Than Usual." USA Today. June 21, 2001.

15. Mazur, Laura. "The Web May be Worldwide but it Still has Borders." Marketing. London; April 26, 2001, p. 24+.

16. Partch, Ken. "Why are E-Grocers Checking Out?" Supermarket Business. New York; Volume 55, Issue 12, December 15, 2000, p74+.

17. Shea and Zivic. "Click and Mortar versus Dot-Com: Who Will Win the Online Grocery Business." Applied Business Research Conference 2001. Cancun, Mexico; March, 2001.

18. Slingsby, Helen. "New Economy: Tesco Enters US Market Via Internet." The Guardian. Manchester (UK); June 26, 2001, p. 20+.

19. Sloane, Martin. "Online Grocery Shopping Struggles to Find its Niche." Houston Chronicle. Houston, Texas; January 3, 2001, p. 4+.

20. Stecklow, Steve. "Tesco, Entering the U.S.'s Online Market, To Take Stake in Safeway's Grocery Works." Wall Street Journal. New York; June 26, 2001, p. A18+.

21. Zivic, Louis and Timothy Shea. "Electronic Commerce in the Retail Food Industry: Price of Being the Late Adopter". Applied Business Research Conference 2000. Puerta Vallarta, Mexico; March, 2000.

22. Zook, Chris. "Manager's Journal”, Wall Street Journal, June 21, 2001, p. A22. 